\title{
Maize response to inoculation with strains of plant growth-promoting bacteria
}

\author{
Janaína Dartora ${ }^{1}$, Vandeir F. Guimarães ${ }^{2}$, Cid R. J. Menezes ${ }^{3}$, \\ Mariângela B. Freiberger ${ }^{4}$, Gustavo Castoldi ${ }^{5}$ \& Edilaine. D. V. Gonçalves ${ }^{6}$ \\ ${ }^{1}$ Instituto Agronômico do Paraná/Área de Produção e Experimentação. Pato Branco, PR. E-mail: janaina_dartora@yahoo.com.br (Corresponding author) \\ ${ }^{2}$ Universidade Estadual do Oeste do Paraná/Centro de Ciências Agrárias/Curso de Agronomia. Marechal Cândido Rondon, PR. E-mail: vandeirfg@yahoo.com.br \\ ${ }^{3}$ Instituto Agronômico do Paraná/Programa Sistemas de Produção. Pato Branco, PR. E-mail: cid.renan@iapar.br \\ ${ }^{4}$ Instituto Federal Goiano/Laboratório de Propagação de Plantas. Rio Verde, GO. E-mail: maia_bf@yahoo.com.br \\ ${ }^{5}$ Instituto Federal Goiano/Rede Arco Norte/Pólo de Inovação. Rio Verde, GO. E-mail: gustavo.castoldi@ifgoiano.edu.br \\ ${ }^{6}$ Universidade Estadual do Oeste do Paraná/Departamento de Fitopatologia. Marechal Cândido Rondon, PR. E-mail: edilainevalentina@gmail.com
}

Key words:

Zea mays L.

Azospirillum sp.

Rhizobium sp.

phytohormones

\begin{abstract}
A B S T R A C T
The aim of this study was to evaluate the response of maize to inoculation with strains of plant growth-promoting bacteria (PGPB) in two cultivation years. The experiment was set in a randomized block design with four replicates in two cultivation years (2012/13 and 2013/14). The treatments consisted of PGPB inoculation: control (without $\mathrm{N}$ and without inoculation); $30 \mathrm{~kg}$ of $\mathrm{N} \mathrm{ha}^{-1}$ at sowing $(\mathrm{N} 1) ; 160 \mathrm{~kg}$ of $\mathrm{N} \mathrm{ha}^{-1}\left(\mathrm{~N} 1+130 \mathrm{~kg}\right.$ of N ha ${ }^{-1}$ as top-dressing); $\mathrm{N} 1+$ A. brasilense, Ab-V5; N1 + A. brasilense, HM053; N1 + Azospirillum sp. L26; N1 + Azospirillum sp. L27; N1 + Enhydrobacter sp. 4331; N1 + Rhizobium sp. 8121. Basal stem diameter, plant height, leaf area, shoot dry matter and yield were evaluated. The strain of Rhizobium sp. 8121and the isolate Azospirillum sp. L26 associated with $30 \mathrm{~kg}$ of $\mathrm{N} \mathrm{ha}^{-1}$ at sowing promoted yields equivalent to that of the $\mathrm{N}$ fertilization of $160 \mathrm{~kg} \mathrm{ha}^{-1}$, demonstrating the potential to be used in the inoculation of maize seeds.
\end{abstract}

Palavras-chave:

Zea mays L. Azospirillum sp. Rhizobium sp. fito-hormônios

\section{Resposta do milho à inoculação de estirpes de bactérias promotoras do crescimento de plantas}

\footnotetext{
R E S U M O

Neste trabalho objetivou-se avaliar a resposta do milho à inoculação de estirpes de bactérias promotoras do crescimento de plantas (BPCP's) em dois anos de cultivo. O experimento foi conduzido em delineamento experimental de blocos ao acaso com quatro repetições em dois anos de cultivo (2012/13 e 2013/14). Os tratamentos foram constituídos pela inoculação de BPCP's: controle (sem $\mathrm{N}$ e sem inoculação); $30 \mathrm{~kg} \mathrm{ha}^{-1} \mathrm{~N}$ na semeadura (N1); $160 \mathrm{~kg} \mathrm{ha}^{-1} \mathrm{~N}$ $\left(\mathrm{N} 1+130 \mathrm{~kg} \mathrm{ha}^{-1} \mathrm{~N}\right.$ em cobertura); $\mathrm{N} 1+$ A. brasilense, Ab-V5; N1 + A. brasilense, HM053; $\mathrm{N} 1+$ Azospirillum sp., L26; N1 + Azospirillum sp., L27; N1 + Enhydrobacter sp. 4331; N1 + Rhizobium sp. 8121. Diâmetro basal do colmo, altura da planta, área foliar, massa seca da parte aérea e produtividade foram avaliados. A estirpe de Rhizobium sp. 8121 e o isolado de Azospirillum sp. L26 associados à adubação com $30 \mathrm{~kg} \mathrm{ha}^{-1} \mathrm{~N}$ na semeadura proporcionaram produtividades equivalentes à adubação com $160 \mathrm{~kg} \mathrm{ha}^{-1} \mathrm{~N}$ demonstrando potencial para serem utilizadas na inoculação de sementes de milho.
} 


\section{INTRODUCTION}

Maize (Zea mays L.) is the main cereal produced in Brazil, with total cultivated area in the $2014 / 15$ season of 15,207 thousand hectares and mean yield of $5,168 \mathrm{~kg} \mathrm{ha}^{-1}$ (CONAB, 2015). Various studies have been conducted under different conditions of soil, climate and cultivation system, showing general response of maize to nitrogen $(\mathrm{N})$ fertilization (Ferreira et al., 2009; Gava et al., 2010; Santos et al., 2010). However, the production process and the need to import $\mathrm{N}$ fertilizers make their acquisition more expensive. In this context, one alternative aiming to optimize their use in the maize crop consists in the association with plant growth-promoting bacteria (PGPB)

The growth-promoting effect caused by the inoculation of PGPB results from the production of phytohormones by the bacteria, as well as other mechanisms of growth promotion, such as the stabilization of phosphates, biological $\mathrm{N}$ fixation (BNF) and the increase in the activity of specific enzymes (Okon \& Vanderleyden, 1997; Rodriguez \& Fraga, 1999; Radwan et al., 2004).

Lana et al. (2012) report positive effect of inoculation with A. brasilense in the absence of $\mathrm{N}$ as top-dressing, with increment of $15 \%$ in maize yield; other studies also highlight the effect of maize growth promotion caused by other PGPB genera, such as: Sphingomonas spp. (Pedrinho et al., 2010), Burkholderia spp. (Alves et al., 2015), Herbaspirillum spp. (Dotto et al., 2010; Araújo et al., 2013) and Rhizobium spp. (Hahn et al., 2014).

The selection of efficient strains is a key factor for the success of inoculation (Hungria et al., 2010). Reis Júnior et al. (2008) isolated different strains of Azospirillum spp. and Herbaspirillum spp. from the root system of maize varieties and observed variable potential regarding the production of auxins (IAA) and BNF, selecting strains that promoted greater plant growth for later studies in greenhouse and at the field. Thus, the present study aimed to evaluate the response of maize to the inoculation of PGPB strains.

\section{Material AND Methods}

The experiment was carried out at the field, in the summer seasons of 2012/13 and 2013/14, at the Experimental Station of the Agronomic Institute of Paraná - IAPAR, in Pato Branco-PR, Brazil (25 $\left.07^{\prime} \mathrm{S} ; 52^{\circ} 41^{\prime} \mathrm{W} ; 700 \mathrm{~m}\right)$. The climate in the region, according to Köppen's classification, is Cfa in transition to $\mathrm{Cfb}$. The data of rainfall and temperature during the study are presented in Figure 1.

The soil in the experimental area, according to the criteria of the Brazilian Soil Classification System - SiBCS (EMBRAPA, 2006), was classified as distroferric Red Latosol, with undulating relief and clayey texture. Its chemical attributes in the layer of $0-20 \mathrm{~cm}$, through the Mehlich-1 extraction method, were: $\mathrm{pH}\left(\mathrm{CaCl}_{2}\right)-4.5 ; \mathrm{P}-10.3 \mathrm{mg} \mathrm{dm}^{-3} ; \mathrm{K}-0.23 \mathrm{cmol}_{\mathrm{c}} \mathrm{dm}^{-3}$; organic matter $-44.2 \mathrm{~g} \mathrm{dm}^{-3} ; \mathrm{Al}^{3+}-0.26 \mathrm{cmol} \mathrm{dm}_{\mathrm{c}}^{-3} ; \mathrm{Ca}-3.91$ $\mathrm{cmol}_{c} \mathrm{dm}^{-3} ; \mathrm{Mg}-1.64 \mathrm{cmol}_{c} \mathrm{dm}^{-3} ; \mathrm{CEC}-11 \mathrm{cmol}_{c} \mathrm{dm}^{-3} ; \mathrm{V} \%-$ $54 ; \mathrm{H}+\mathrm{Al}-4.96 \mathrm{cmol} \mathrm{dm}^{-3}$ and SB -5.78 .

In the winter cultivation, prior to experiment installation, the area was cultivated by an intercropping of cover crops:

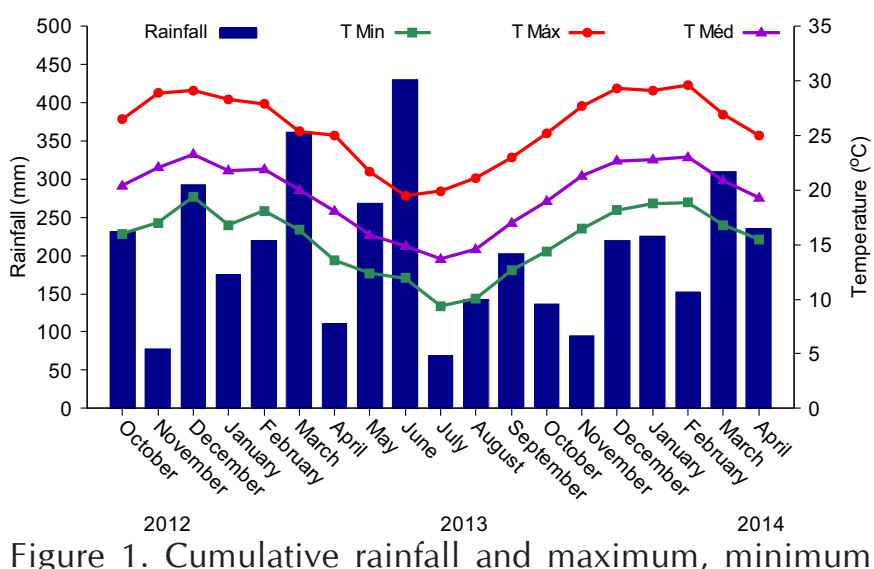

and medium temperatures per month in the period from October 2012 to April 2014

common radish (Raphanus sativus L.), field pea (Pisum arvense L.), common vetch (Vicia sativa L.) and black oat (Avena strigosa Schreb.), sown on May 15, 2012. Cover crops were managed with a cutting roller on August 23, 2012, and desiccation on October 16, 2012, with the non-selective herbicide glyphosate [2.5 L of the commercial product (c.p.) $\mathrm{ha}^{-1}$. Between the maize crops of 2012/13 and 2013/14, black oat (cultivar Iapar 61) was sown broadcast in the cultivation area on June 19, 2013, and desiccated with glyphosate $(2.5 \mathrm{~L}$ c.p. ha ${ }^{-1}$ ) on October 30, 2013.

The experiment was set in randomized blocks with four replicates in two cultivation years, corresponding to the seasons of 2012/13 and 2013/14. The treatments consisted of inoculation of PGPB strains: control (without $\mathrm{N}$ and without inoculation); $30 \mathrm{~kg}$ of $\mathrm{N} \mathrm{ha}^{-1}$ at sowing (N1); $160 \mathrm{~kg}$ of $\mathrm{N} \mathrm{ha}^{-1}$ (30 kg ha ${ }^{-1}$ at sowing $+130 \mathrm{~kg} \mathrm{ha}^{-1}$ as top-dressing); $\mathrm{N} 1+$ inoculation with $A$. brasilense, strain $\mathrm{Ab}-\mathrm{V} 5 ; \mathrm{N} 1+$ inoculation with $A$. brasilense, strain HM053; N1 + inoculation with Azospirillum sp., strain L26; N1 + inoculation with Azospirillum sp., strain L27; N1 + inoculation with Enhydrobacter sp. strain 4331; N1 + inoculation with Rhizobium sp. strain 8121 .

The single-cross maize hybrid 30F53 Herculex ${ }^{\circledR}$ was evaluated and its seeds were inoculated $12 \mathrm{~h}$ before sowing, at the proportion of $20 \mathrm{~mL}$ of the inoculant for each $\mathrm{kg}$ of seeds. The inoculants were prepared and provided by the Federal University of Paraná (UFPR), from a pure solution of bacteria at the concentration of $10^{9}$ cells $\mathrm{mL}^{-1}$. The strains HM053 and $\mathrm{Ab}-\mathrm{V} 5$ are registered by the Ministry of Agriculture and the others were recently isolated from the roots of the maize variety 'Sol da Manhã, in Santo Antônio de Goiás-GO (L26 and L27) and from the roots of a double-cross hybrid (AG 2040) in Londrina-PR (4331 and 8121).

Sowing was performed using handheld maize planters (called "matracas") on October 25, 2012, and November 14, 2013. Each experimental unit consisted of six 5-m-long rows ( $0.8 \mathrm{~m}$ between rows) with five plants per linear meter. Fertilization was performed based on soil chemical analysis and on recommendations proposed by IAPAR (2003), through the application of $50 \mathrm{~kg} \mathrm{ha}^{-1}$ of $\mathrm{P}_{2} \mathrm{O}_{5}$ and $50 \mathrm{~kg} \mathrm{ha}^{-1}$ of $\mathrm{K}_{2} \mathrm{O}$ in the sowing furrow, in both experiments. The fertilizers single superphosphate $\left(18 \%\right.$ of $\left.\mathrm{P}_{2} \mathrm{O}_{5}\right)$ and potassium chloride $(58 \%$ of $\mathrm{K}_{2} \mathrm{O}$ ) were used as sources of $\mathrm{P}$ and $\mathrm{K}$, respectively. After 
sowing, $\mathrm{N}$ fertilization was applied via broadcast, in the form of urea $(46 \%$ of $\mathrm{N})$ except for the control treatment. The rest of the $\mathrm{N}$ dose, for the treatment with $160 \mathrm{~kg}$ of $\mathrm{N} \mathrm{ha}^{-1}$, was applied as top-dressing in the V6 stage (Weismann, 2008). Phytosanitary tracts were performed according to the necessity and the recommendations for the crop.

Two plants were randomly collected in each plot for biometric evaluations in the vegetative (V8 - eight developed leaves) and reproductive (R1 - appearance of style-stigmas on the ear) stages. Before plant collection, basal stem diameter was measured at $5 \mathrm{~cm}$ from the soil surface and the canopy height was measured between the base and the highest point of the plant. Sampled plants were collected and dried in a forced-air oven at $65 \pm 2{ }^{\circ} \mathrm{C}$ for $72 \mathrm{~h}$, for the determination of shoot dry matter. Leaf area was determined by the method of dry matter of leaf discs, proposed by Benincasa (2003).

Harvest was manually performed on March 26, 2013, and on April 16, 2014, by collecting all ears from the evaluation area of the plot (two 3-m-long central rows). Grain yield was calculated based on the production of the evaluation area of each plot, in $\mathrm{kg} \mathrm{ha}^{-1}$, after correcting the moisture content to $13 \%$.

The data were subjected to analysis of variance using the program GENES (Cruz, 2006) and means were compared by Tukey test at 0.05 probability level.

\section{Results AND Discussion}

In the 2012/13 season, there was effect of inoculation on the variables plant height, in both development stages (V8 and R1), and stem diameter, in V8 (Table 1). However, in the 2013/14 season, the effect occurred on plant height (V8 and $\mathrm{R} 1$ ), stem diameter (V8), shoot dry matter (R1), leaf area (V8 and R1) and grain yield (Table 1).

In the 2012/13 season, for plant height in the V8 stage, the inoculation with the strain HM053 promoted increment of 33 $\mathrm{cm}(25 \%)$ in relation to the control, but without differing from the other treatments (Table 2). In the R1 stage, the inoculation with the strain HM053 and $\mathrm{N}$ fertilization of $160 \mathrm{~kg} \mathrm{ha}^{-1}$ were superior to the control and to the $\mathrm{N}$ fertilization of $30 \mathrm{~kg} \mathrm{ha}^{-1}$, and similar to the other treatments (Table 2). However, in the 2013/14 season, all treatments, except $\mathrm{N}$ fertilization of $30 \mathrm{~kg}$ $\mathrm{ha}^{-1}$, showed greater plant height compared with the control in V8 (Table 3). Such behavior occurred again in R1 and the control treatment showed lower plant height in comparison to the others, except for the treatment with $30 \mathrm{~kg}$ of $\mathrm{N} \mathrm{ha}^{-1}$ and the inoculation with the strains Ab-V5 and HM053 (Table 3).

Plant height is a genetic characteristic influenced by the environment in which the plant develops and on which the availability of nutrients has great impact. Thus, the inoculation of PGPB may have promoted an effect similar to that of $\mathrm{N}$ fertilization, stimulating the development of plant roots and their potential of absorption of nutrients (Albuquerque et al., 2013).

As to the basal stem diameter in the V8 stage, in the 2012/13 season, the inoculation of the isolate HM053 surpassed the control treatment and the inoculation of the strain L27, without differing from the other treatments (Table 2). However, in

Table 1. Summary of the analysis of variance for the variables plant height (PH), basal stem diameter (SD), shoot dry matter (SDM), leaf area (LA), in the stages V8 and R1, and grain yield (YIELD) of hybrid maize (30F53) in the seasons of 2012/13 and 2013/14, as a function of seed inoculation with strains of growth-promoting bacteria

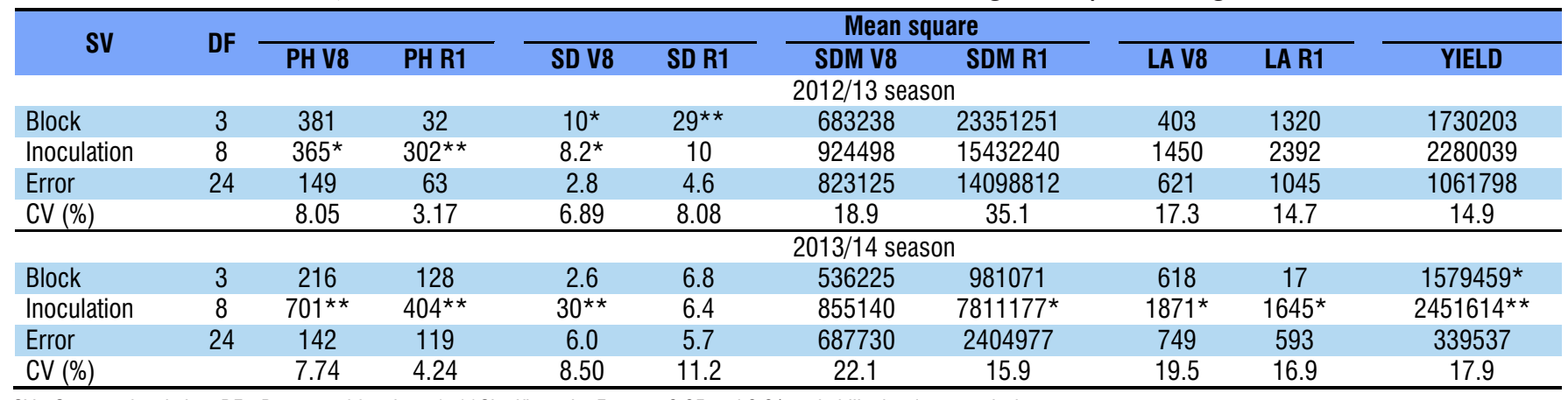

SV - Source of variation; DF - Degrees of freedom; * ${ }^{*}$ Significant by $F$ test at 0.05 and 0.01 probability level, respectively.

Table 2. Plant height (PH), basal stem diameter (SD), shoot dry matter (SDM) and leaf area (LA), in the stages V8 and R1, and grain yield (YIELD) of hybrid maize (30F53) in the 2012/13 season, as a function of seed inoculation with strains of growth-promoting bacteria

\begin{tabular}{|c|c|c|c|c|c|c|c|c|c|}
\hline \multirow[b]{2}{*}{ Treatment } & \multicolumn{4}{|c|}{ V8 stage } & \multicolumn{4}{|c|}{ R1 stage } & \multirow[b]{2}{*}{$\begin{array}{l}\text { YIELD } \\
\mathrm{kg} \mathrm{ha}^{-1}\end{array}$} \\
\hline & $\begin{array}{l}\mathrm{PH} \\
\mathrm{cm}\end{array}$ & $\begin{array}{c}\mathrm{SD} \\
\mathrm{mm}\end{array}$ & $\begin{array}{l}\text { SDM } \\
\mathrm{kg} \mathrm{ha}^{-1}\end{array}$ & $\begin{array}{c}\mathrm{LA} \\
\mathrm{dm}^{2}\end{array}$ & $\begin{array}{l}\mathrm{PH} \\
\mathrm{cm}\end{array}$ & $\begin{array}{c}\mathrm{SD} \\
\mathrm{mm}\end{array}$ & $\begin{array}{c}\text { SDM } \\
\mathrm{kg} \mathrm{ha}^{-1}\end{array}$ & $\begin{array}{c}\mathrm{LA} \\
\mathrm{dm}^{2}\end{array}$ & \\
\hline Control & $132 \mathrm{~b}$ & $23 b$ & 3,995 & 108 & $236 \mathrm{c}$ & 24 & 6,788 & 172 & 5,852 \\
\hline $30 \mathrm{~kg}$ of $\mathrm{N} \mathrm{ha}^{-1}$ & $144 a b$ & $25 a b$ & 4,863 & 134 & $241 b c$ & 26 & 9,906 & 199 & 6,102 \\
\hline $160 \mathrm{~kg}$ of $\mathrm{N} \mathrm{ha}^{-1}$ & $157 a b$ & $24 a b$ & 4,804 & 155 & $260 \mathrm{a}$ & 29 & 13,291 & 241 & 7,199 \\
\hline A. brasilense $(\mathrm{Ab}-\mathrm{V} 5)+30 \mathrm{~kg}$ of $\mathrm{N} \mathrm{ha}^{-1}$ & $157 \mathrm{ab}$ & $26 a b$ & 5,087 & 159 & $256 a b$ & 27 & 12,403 & 234 & 6,538 \\
\hline A. brasilense (HM053) $+30 \mathrm{~kg}$ of $\mathrm{N} \mathrm{ha}^{-1}$ & $165 \mathrm{a}$ & $27 \mathrm{a}$ & 5,687 & 174 & $260 \mathrm{a}$ & 28 & 11,020 & 232 & 7,871 \\
\hline Azospirillum sp. (L26) $+30 \mathrm{~kg}$ of N ha-1 & $157 \mathrm{ab}$ & $25 a b$ & 4,930 & 147 & $258 \mathrm{ab}$ & 28 & 10,219 & 251 & 7,718 \\
\hline Azospirillum sp. (L27) + $30 \mathrm{~kg}$ of $\mathrm{N} \mathrm{ha}^{-1}$ & $147 a b$ & $23 \mathrm{~b}$ & 4,262 & 130 & $248 a b c$ & 26 & 9,291 & 205 & 6,509 \\
\hline Enhydrobacter sp. (4331) $+30 \mathrm{~kg}$ of N ha-1 & $154 a b$ & $25 a b$ & 4,661 & 142 & $254 a b c$ & 25 & 10,812 & 220 & 7,673 \\
\hline Rhizobium sp. (8121) + $30 \mathrm{~kg}$ of N ha-1 & $154 a b$ & $24 a b$ & 4,850 & 148 & $255 a b$ & 27 & 12,428 & 218 & 6,403 \\
\hline Mean & 152 & 24.5 & 4,793 & 144 & 252 & 27 & 10,684 & 219 & 6,874 \\
\hline
\end{tabular}

Means followed by different letters in the column differ significantly by Tukey test at 0.05 probability level 
Table 3. Plant height (PH), basal stem diameter (SD), shoot dry matter (SDM) and leaf area (LA), in the stages V8 and R1, and grain yield (YIELD) of hybrid maize (30F53) in the 2013/14 season, as a function of seed inoculation with strains of growth-promoting bacteria

\begin{tabular}{|c|c|c|c|c|c|c|c|c|c|}
\hline \multirow[b]{2}{*}{ Treatment } & \multicolumn{4}{|c|}{ V8 stage } & \multicolumn{4}{|c|}{ R1 stage } & \multirow{2}{*}{$\begin{array}{l}\text { YIELD } \\
\text { kg ha }^{-1}\end{array}$} \\
\hline & $\begin{array}{l}\mathrm{PH} \\
\mathrm{cm}\end{array}$ & $\begin{array}{l}\text { SD } \\
\mathrm{mm}\end{array}$ & $\begin{array}{c}\text { SDM } \\
\mathrm{kg} \mathrm{ha}^{-1}\end{array}$ & $\begin{array}{l}\text { LA } \\
\mathrm{dm}^{2}\end{array}$ & $\begin{array}{l}\mathrm{PH} \\
\mathrm{cm}\end{array}$ & $\begin{array}{l}\text { SD } \\
\mathrm{mm}\end{array}$ & $\begin{array}{c}\text { SDM } \\
\mathrm{kg} \mathrm{ha}^{-1}\end{array}$ & $\begin{array}{l}\mathrm{LA} \\
\mathrm{dm}^{2}\end{array}$ & \\
\hline Control & 122 b & $24 \mathrm{~b}$ & 2,792 & $92 \mathrm{~b}$ & $233 \mathrm{~b}$ & 19 & $7,541 \mathrm{~b}$ & $105 b$ & $2,555 \mathrm{~cd}$ \\
\hline $30 \mathrm{~kg}$ of $\mathrm{N} \mathrm{ha}^{-1}$ & $147 \mathrm{ab}$ & $28 a b$ & 3,225 & $122 a b$ & $257 \mathrm{ab}$ & 21 & $8,741 \mathrm{ab}$ & $132 a b$ & $2,840 \mathrm{~cd}$ \\
\hline $160 \mathrm{~kg}$ of $\mathrm{N} \mathrm{ha}^{-1}$ & $160 \mathrm{a}$ & $30 \mathrm{a}$ & 3,908 & $152 a b$ & $268 \mathrm{a}$ & 22 & $11,105 a b$ & $161 \mathrm{ab}$ & $4,536 \mathrm{a}$ \\
\hline A. brasilense $(\mathrm{Ab}-\mathrm{V} 5)+30 \mathrm{~kg}$ of $\mathrm{N} \mathrm{ha}^{-1}$ & $163 \mathrm{a}$ & $32 \mathrm{a}$ & 4,235 & $151 \mathrm{ab}$ & $256 a b$ & 21 & $9,643 a b$ & $135 a b$ & $3,229 \mathrm{bcd}$ \\
\hline A. brasilense $(\mathrm{HM} 053)+30 \mathrm{~kg}$ of $\mathrm{N} \mathrm{ha}^{-1}$ & $159 a$ & $27 a b$ & 3,859 & $146 a b$ & $260 \mathrm{ab}$ & 19 & 8,242 b & $128 a b$ & $2,364 \mathrm{~d}$ \\
\hline Azospirillum sp. (L26) $+30 \mathrm{~kg}$ of $\mathrm{N} \mathrm{ha}^{-1}$ & $164 \mathrm{a}$ & $32 \mathrm{a}$ & 3,980 & $144 \mathrm{ab}$ & $265 \mathrm{a}$ & 23 & $11,975 \mathrm{a}$ & $170 \mathrm{a}$ & $3,779 \mathrm{abc}$ \\
\hline Azospirillum sp. (L27) + $30 \mathrm{~kg}$ of $\mathrm{N} \mathrm{ha}^{-1}$ & $160 \mathrm{a}$ & $29 a b$ & 3,757 & $145 a b$ & $261 \mathrm{a}$ & 22 & $10,000 a b$ & $151 \mathrm{ab}$ & $2,556 \mathrm{~cd}$ \\
\hline Enhydrobacter sp. (4331) $+30 \mathrm{~kg}$ of N ha-1 & $158 \mathrm{a}$ & $26 a b$ & 3,721 & $145 a b$ & $262 \mathrm{a}$ & 22 & $9,803 \mathrm{ab}$ & $153 a b$ & $3,118 \mathrm{bcd}$ \\
\hline Rhizobium sp. $(8121)+30 \mathrm{~kg}$ of N ha-1 & $156 \mathrm{a}$ & $32 \mathrm{a}$ & 4,187 & $167 \mathrm{a}$ & $261 \mathrm{a}$ & 22 & $10,517 \mathrm{ab}$ & $158 a b$ & $4,267 a b$ \\
\hline Mean & 154 & 29 & 3,740 & 140 & 258 & 21 & 9,730 & 144 & 3,249 \\
\hline
\end{tabular}

Means followed by different letters in the column differ significantly by Tukey test at 0.05 probability level

the 2013/14 season, the $\mathrm{N}$ fertilization of $160 \mathrm{~kg} \mathrm{ha}^{-1}$ and the inoculation with the strains Ab-V5, L26 and Rhizobium sp. 8121 showed higher values of stem diameter in the V8 stage in comparison to the control treatment, but without differing from the others (Table 3). Ramos et al. (2010) observed that the inoculation of Azospirillum associated or not with $\mathrm{N}$ fertilization at sowing $\left(30 \mathrm{~kg} \mathrm{ha}^{-1}\right)$ surpassed the control treatment for collar diameter of maize plants. Increments in the development of maize stem diameter are directly related to the increments of the individual plant production, due to its function in the storage of soluble solids that may be used later, in the formation of grains (Fancelli \& Dourado Neto, 2000).

The results of plant height and basal stem diameter, in general, show that the inoculation with PGPB, combined with $30 \mathrm{~kg}$ of $\mathrm{N} \mathrm{ha}^{-1}$, did not differ from the $\mathrm{N}$ fertilization of $160 \mathrm{~kg} \mathrm{ha}^{-1}$. According to Siqueira et al. (1999), when plants are colonized by Azospirillum, there is an increase in root hair density, rate of appearance of secondary roots and root surface, due to the production of phytohormones by the bacterium, with modifications not only in growth, but also in the morphology and density of root hairs. Such effect stimulates the absorption of water and nutrients from the soil, favoring the development of the plant as a whole.

For shoot dry matter and leaf area in the 2012/13 season, there was no effect of inoculation in both maize development stages (Table 2), while in the 2013/14 season shoot dry matter, in the R1 stage, was higher for the inoculation of the isolate L26 and lower in the control treatment and for the inoculation of the strain HM053 (Table 3). Still in the 2013/14 season, the highest values of leaf area, in comparison to the control treatment, were observed in the treatments with inoculation of Rhizobium sp. 8121 (V8) and the isolate L26 (R1); the other treatments showed intermediate and similar values of leaf area (Table 3).

The similar results between the inoculation of the strains associated with the $\mathrm{N}$ fertilizations of $30 \mathrm{~kg} \mathrm{ha}^{-1}$ and $160 \mathrm{~kg}$ $\mathrm{ha}^{-1}$ reflect the effect of growth promotion caused by the PGPB, involving a set of mechanisms besides the production of phytohormones, such as biological control of phytopathogens, BNF and solubilization of phosphates (Bashan \& Levanony, 1990; Pidello et al., 1993). In addition, the inoculation of PGPB associated with low $\mathrm{N}$ doses has shown greater efficiency for the plant-bacteria system, in comparison to isolated inoculation, while the application of high $\mathrm{N}$ doses reduces such efficiency due to the plant response to the stimulation in the absorption of the nutrient, limiting the biological process (Bárbaro et al., 2008).

For grain yield in the 2012/13 season, there was no difference between the treatments (Table 2). The lack of response of maize to the inoculation, as well as to the conventional top-dressing fertilization, may be associated with the favorable climatic conditions along the crop cycle (Figure 1) and the high yield in the control treatment. This high yield in the control treatment without $\mathrm{N}$ fertilization is due to the natural stock of $\mathrm{N}$ in the experimental area, since maize was cultivated after an intercropping of cover plants mainly composed of leguminous plants with low $\mathrm{C} / \mathrm{N}$ ratio, increasing $\mathrm{N}$ availability in the system and its absorption by the plant (Bortolini et al., 2000).

In the $2013 / 14$ season, the $\mathrm{N}$ fertilization of $160 \mathrm{~kg} \mathrm{ha}^{-1}$ promoted mean yield of $4,536 \mathrm{~kg} \mathrm{ha}^{-1}$, surpassing the control treatment and those with $\mathrm{N}$ fertilization of $30 \mathrm{~kg} \mathrm{ha}^{-1}$ and seed inoculation with the strains Ab-V5 and HM053 and with the isolates L27 and 4331. In this same year, the strain of Rhizobium sp. 8121 and the isolate L26 stood out with mean yields of 4,267 and $3,779 \mathrm{~kg} \mathrm{ha}^{-1}$, respectively, representing increments of 50 and $33 \%$ in relation to the isolated use of basal $\mathrm{N}$ fertilization $\left(30 \mathrm{~kg} \mathrm{ha}^{-1}\right.$ ), demonstrating the potential of the strain under these cultivation conditions.

It is also noticeable the difference in yield between the cultivation years; in the 2012/13 season, the mean maize yield was $6,874 \mathrm{~kg} \mathrm{ha}^{-1}$ (Table 2), while in the $2013 / 14$ season it was only $3,249 \mathrm{~kg} \mathrm{ha}^{-1}$ (Table 3 ), representing a reduction of $53 \%$. The expressive yield reduction in the 2013/14 season reflects the response of the plants to the abiotic stress suffered at the beginning of the development, despite the favorable climatic conditions (Figure 1), with the occurrence of storm with strong wind gusts between the stages V6 and V8, causing a random "lodging" of the plants. According to Weismann (2008), a decrease of 10 to $25 \%$ in yield may occur if the total distribution of leaves in the V8 stage is altered by the occurrence of biotic/ abiotic factor. In addition, in the V8 stage, the plant finishes the definition of the number of grain rows on the ear (Weismann, 2008); therefore, it is more sensitive to stress in this period.

The results of the present study show that, despite being in the same cultivation area, the PGPB strains have different behaviors, due to abiotic variations. Thus, more studies on the behavior and selection of strains under different 
edaphoclimatic conditions must be conducted in order to consolidate the promising results that some strains showed in the present study. The possibility of combining strains that are efficient and show different behavior in the same inoculant may represent a viable alternative to potentiate the benefits of inoculation in maize.

\section{Conclusion}

The strain Rhizobium sp. 8121and the isolate Azospirillum sp. L26, associated with $\mathrm{N}$ fertilization of $30 \mathrm{~kg} \mathrm{ha}^{-1}$, promoted yields equivalent to that of $\mathrm{N}$ fertilization of $160 \mathrm{~kg} \mathrm{ha}^{-1}$, demonstrating great potential to be used in the inoculation of maize seeds.

\section{ACknowledgments}

To the Araucária Foundation for Scientific and Technological Development of Paraná, affiliated to the State Secretariat of Science, Technology and Higher Education - SETI; to the Coordination for the Improvement of Higher Education Personnel (CAPES/PNPD) and the National Council for Scientific and Technological Development (CNPq/INCT), for the financial support.

\section{Literature Cited}

Albuquerque, A. W.; Santos, J. R.; Filho, G. M.; Reis, L. S. Plantas de cobertura e adubação nitrogenada na produção de milho em sistema de plantio direto. Revista Brasileira de Engenharia Agrícola e Ambiental, v.17, p.721-726, 2013. http://dx.doi. org/10.1590/S1415-43662013000700005

Alves, G. C.; Videira, S. S.; Urquiaga, S.; Reis, V. M. Differential plant growth promotion and nitrogen fixation in two genotypes of maize by several Herbaspirillum inoculants. Plant Soil, v.387, p.307-321, 2015. http://dx.doi.org/10.1007/s11104-014-2295-2

Araújo, F. F. de; Foloni, J. S. S.; Wutzke, M.; Melegari, A. da S.; Rack, E. Híbridos e variedades de milho submetidos à inoculação de sementes com Herbaspirillum seropedicae. Semina, v.34, p.10431054, 2013.

Bárbaro, I. M.; Brancalião, S. R.; Ticelli, M. É possível a fixação biológica de nitrogênio no milho? Pesquisa e Tecnologia, v.5, p.1-8, 2008.

Bashan, Y.; Levanony, H. Current status of Azospirillum inoculation technology: Azospirillum as a challenge for agriculture. Canadian Journal of Microbiology, v.36, p.591-698, 1990. http://dx.doi. org/10.1139/m90-105

Benincasa, M. M. P. Análise de crescimento de plantas: Noções básicas. 2.ed. Jaboticabal: FUNEP, 2003. 42p.

Bortolini, C. G.; Silva, P. R. F.; Argenta, G. Sistemas consorciados de aveia preta e ervilhaca comum como cobertura de solo e seus efeitos na cultura do milho em sucessão. Revista Brasileira de Ciência do Solo, v.24, p.897-903, 2000. http://dx.doi.org/10.1590/ S0100-06832000000400021

CONAB - Companhia Nacional de Abastecimento. <http//www. conab.gov.br>. 13 Mai. 2015.

Cruz, C. D. Programa Genes: Biometria. Viçosa: UFV, 2006. 382p.
Dotto, A. P.; Lana, M. do C.; Steiner, F.; Frandoloso, J. F. Produtividade do milho em resposta à inoculação com Herbaspirillum seropedicae sob diferentes níveis de nitrogênio. Revista Brasileira de Ciências Agrárias, v.5, p.376-382, 2010. http://dx.doi.org/10.5039/agraria. v5i3a898

EMBRAPA - Centro Nacional de Pesquisa de Solos. Sistema brasileiro de classificação de solos. 2. ed. Brasília: EMBRAPA-SPI, 2006. $306 \mathrm{p}$.

Fancelli, A. L.; Dourado Neto, D. Ecofisiologia e fenologia. Produção de milho. Guaíba: Agropecuária, 2000. p.21-54.

Ferreira, A. de. O.; Sá, J. C. de M.; Briedis, C.; Figueiredo, A. G. de. Desempenho de genótipos de milho cultivados com diferentes quantidades de palha de aveia-preta e doses de nitrogênio. Pesquisa Agropecuária Brasileira, v.44, p.173-179, 2009. http:// dx.doi.org/10.1590/S0100-204X2009000200009

Gava, G. J. de C.; Oliveira, M. W. de; Silva, M. de A.; Jerônimo, E. M.; Cruz, J. C. S.; Trivelin, P. C. O. Produção de fitomassa e acúmulo de nitrogênio em milho cultivado com diferentes doses de $15 \mathrm{~N}$-uréia. Semina, v.31, p.851-862, 2010. http://dx.doi.org/10.5433/16790359.2010v31n $4 \mathrm{p} 851$

Hahn, L.; Sá, E. L. S.; Machado, R. G.; Silva, W. R.; Oldra, S.; Damasceno, R. G.; Chönhofen, A. Growth promotion in maize with diazotrophic bacteria in succession with ryegrass and white clover. American-Eurasian Journal of Agricultural \& Environmental Sciences, v.14, p.11-16, 2014.

Hungria, M. Inoculação com Azospirillum brasilense: inovação em rendimento a baixo custo. Londrina: Embrapa Soja. 2011. 36p.

IAPAR - Instituto Agronômico do Paraná. Sugestão de adubação e calagem para culturas de interesse econômico no estado do Paraná. Londrina: IAPAR, 2003. 30p. Circular n.128.

Lana, M. do C.; Dartora, J.; Marini, D.; Hann, J. E. H. Inoculation with Azospirillum, associated with nitrogen fertilization in maize. Revista Ceres, v.59, p.399-405, 2012. http://dx.doi.org/10.1590/ S0034-737X2012000300016

Okon, Y; Vanderleyden, J. Root-associated Azospirillum species can stimulate plants. Applied and Environmental Microbiology, v.63, p.366-370, 1997.

Pedrinho, E. A. N.; Galdiano Júnior, R. F.; Campanharo, J. C.; Alves, L. M. C.; Lemos, E. G. de M. Identificação e avaliação de rizobactérias isoladas de raízes de milho. Bragantia, v.69, p.905-911, 2010. http://dx.doi.org/10.1590/S0006-87052010000400017

Pidello, A; Menendez, L; Lensi, R. Azospirillum affects Eh and potential denitrification in a soil. Plant and Soil, v.157, p.31-34, 1993. http://dx.doi.org/10.1007/BF02390224

Radwan, T. E. E; Mohamed, Z. K; Reis, V. M. Efeito da inoculação de Azospirillum e Herbaspirillum na produção de compostos indólicos em plântulas de milho e arroz. Pesquisa Agropecuária Brasileira, v.39, p.987-994, 2004. http://dx.doi.org/10.1590/S0100204X2004001000006

Ramos, A. S; Santos, T. M. C. dos; Santana, T. M. de; Guedes, É. L. F; Montaldo, Y. C. Ação do Azospirillum lipoferum no desenvolvimento de plantas de milho. Revista Verde de Agroecologia e Desenvolvimento Sustentável, v.5, p.113-117, 2010.

Reis Junior, F. B. dos; Machado, C. T. de T.; Machado, A. T.; Sodek, L. Inoculação de Azospirillum amazonense em dois genótipos de milho sob diferentes regimes de nitrogênio. Revista Brasileira de Ciência do Solo, v.32, p.1139-1146, 2008. http://dx.doi. org/10.1590/S0100-06832008000300022 
Rodriguez, H.; Fraga, R. Phosphate solubilizing bacteria and their role in plant growth promotion. Biotechnology Advances, v.17, p.319339, 1999. http://dx.doi.org/10.1016/S0734-9750(99)00014-2

Santos, M. M.; Galvão, J. C. C.; Silva, I. R.; Miranda, G. V.; Finger, F. L. Épocas de aplicação de nitrogênio em cobertura na cultura do milho em plantio direto, e alocação do nitrogênio (15N) na planta. Revista Brasileira de Ciência do Solo, v.34, p.1185-1194, 2010. http://dx.doi.org/10.1590/S0100-06832010000400018
Siqueira, J. O.; Moreira, F. M. S.; Lopes, A. S.; Guilherme, L. R. G.; Faquin, V.; Furtini Neto, A. E.; Carvalho, J. G. Inter-relação fertilidade, biologia do solo e nutrição de plantas. Viçosa: SBCS. Lavras: UFLA/DCS, 1999. 818p.

Weismann, M. Fases de desenvolvimento da cultura do milho. In: Tecnologias e produção: Milho safrinha e culturas de inverno. Maracaju: Fundação MS, 2008. p.31-38. 